Urszula Szuścik

https://doi.org/10.26881/pwe.2021.52.01

ORCID: 0000-0003-0817-4868

Uniwersytet Śląski w Katowicach

urszula.szuscik@us.edu.pl

\title{
Bazgrota w twórczości plastycznej dziecka - obszar wciąż niedoceniany
}

\section{Summary \\ Scribble in a child's art work - an area still underestimated}

The article is theoretical. It presents the value of scribble in the development of a child's drawing creativity. As a result of the theoretical analysis of the problem of scribbling in a child's drawing, the author defined the following features of the scribble, such as: dynamics of change, spontaneity of action, elementary kinesthetic in building a form, non-objectivity, own internal rhythm of drawing and painting, subjectivity, projection of the form of physical activity, fabulous content, novelty results, originality of the approach, expressiveness. The time for free scribbling of a child, which is assigned to him in his first stage of development of drawing creativity, is an important time for his creative development, motivation to learn and action, which will give him a good basis for further stages of his activities and learning.

Keywords: child, scribble, creativity, drawing, education

Słowa kluczowe: dziecko, bazgrota, twórczość, rysunek, edukacja

\section{Wprowadzenie}

Twórczość plastyczna dziecka w wieku przedszkolnym i wczesnoszkolnym przypada na najbardziej dynamiczny okres jego kształtowania się i zarazem określa charakter rozwoju rysunku dziecka i jego przemian. Tak intensywne i szybkie zmiany rozwojowe w tym okresie życia dziecka są jedyne i niepowtarzalne. Ewolucja rysunku dziecka i dynamika zmiany rozwojowej, widoczne w przestrukturyzowaniu formy rysunku, już nigdy nie będą tak wyraziste. Bazgrocie, bazgraniu nadaje się pejoratywne znaczenie w języku potocznym i ocenie pedagogicznej. W edukacji przedszkolnej dziecka jest to okres często lekceważony przez rodziców i nauczycieli, tzn. nie przywiązuje się do tej aktywności rysunkowej dziecka wystarczającej wagi i nie poświęca na nią czasu. W rozwoju rysunkowym dziecka ważnym i jednocześnie mało zbadanym okresem jest właśnie okres bazgrot (od 1,5 roku do 3 lat), który można przyjąć za znaczący w ogólnym rozwoju dziecka, dlatego że odzwierciedla jego rozwój fizyczny i psychiczny. Uważam, że zwrócenie uwagi na ten 
okres w twórczości rysunkowej dziecka jest istotny ze względu na wnioski dla praktyki pedagogicznej i na obserwację rozwoju dziecka.

Badań poświęconych w całości bazgrocie dziecięcej, a nie opisowi tego okresu w ogólnym ujęciu rozwoju twórczości plastycznej dziecka, jest bardzo mało. Na całym świecie zagadnieniem tym zajmuje się tylko jedna znana badaczka - amerykańska psycholog i naukowiec Rhody Kellog (Kellog, O’Dell 1967; Kellog 1969), na jej badania powołują zagraniczni naukowcy, m.in. Hans-Günther Richter (1997), Antonio Machón (2013), jej wyniki badań przywołują oni w charakterystyce okresu bazgroty w rozwoju twórczości plastycznej dziecka.

Rhoda Kellog (1969) przeanalizowała rysunki dzieci w wieku 2-8 lat. W literaturze zaznacza się, że to ona po raz pierwszy przedstawiła historię bazgroty (Richter 1997: 306). W polskiej literaturze naukowej, w której poddano badaniom bazgrotę dziecięcą, jest również tylko jedna taka publikacja, autorstwa Marii Parnowskiej-Kwiatowskiej (1960), pedagog, psycholog, która zwróciła uwagę na wartość bazgroty w rozwoju twórczości rysunkowej dziecka, opisała jej cechy oraz wskazała konieczność podjęcia badań nad tym tematem. W swoich ostatnich dociekaniach badawczych nad twórczością plastyczną dziecka Urszula Szuścik (2019) objęła analizą bazgrotę, jej strukturę, cechy rozwojowe oraz jej kształtowanie się w wyniku kształcenia percepcji wzrokowej dziecka w wieku 2-3 lat. Przyjmuje ona, że bazgrota zapoczątkowuje pewien rodzaj ekspresji, która porządkuje i strukturyzuje działanie dziecka w toku rozwoju bazgroty oraz daje podstawy do przyszłej nauki w szkole.

W artykule przedstawię dotychczasowe rozważania teoretyczne nad bazgrotą, które można wysnuć z całościowych charakterystyk okresów twórczości plastycznej ujmujących również okres bazgroty. Co jest tak fascynującego i ważnego w bazgrocie dziecięcej dla dziecka, dla jego rozwoju? Co daje nauczycielowi, opiekunowi wiedza na ten temat, czy pozwala iść równolegle z dzieckiem, a nie „przerzucać” je ponad drogą jego rytmu rozwojowego, dzięki któremu zyskuje równowagę i podstawę do wejścia w następny okres rozwoju rysunkowego i życiowego?

\section{Bazgroty - wybrane stanowiska badawcze}

Patrząc na pierwsze rysunki dziecka, zadajemy sobie pytanie: co to takiego jest bazgrota? Czy jest to bezmyślne, przypadkowe rysowanie, wyrażające impulsywne uzewnętrznianie uczuć ogólnych, jak je określa Herbert Read (1976: 121)? Czy jest ono wynikiem głębszych przemian i procesów zachodzących w rozwoju dziecka, jako kinestetyczna elementarna forma, która zmierza do integracji ze światem (Read 1976: 123)? Jest to swoista zagadka w rozwoju dziecka. Bazgrotę cechuje spontaniczność, tzn. dziecko ma możliwość uzewnętrzniania siebie bez jakichkolwiek przeszkód. Jest to aktywność psychiczna, która ma różną rangę i różny stopień, co wyznaczają poszczególne etapy rozwoju bazgroty. Rysunek staje się środkiem zaspokojenia ekspresji dziecka. Maurice Debesse (1988: 221), 
powołując się na poglądy Pierre’a Naville’a, określa bazgroty w twórczości dziecka jako „gaworzenie graficzne”, które wyprzedza rysunek. Zdaniem Georga Kerschensteinera (za: Borzym 1968: 595) pierwsze wytwory dzieci nie zasługują na miano rysunków, są tylko pozbawionymi formy bazgrotami. Z kolei na wartość bazgroty zwrócił uwagę Walther Krötzsch, który wyróżnił kilka momentów rozwojowych pierwotnych bazgrot. Wskazał na znaczenie rytmu poprzedzającego pojawienie się kształtu w rysunkach dziecka. „Ruch i radość ruchu są początkiem i zasadą. Rysowanie jest dokładnym obrazem ruchu. Ruch początkowo jest prosty i szeroki, następnie staje się drobniejszy, krótszy i wielostronny. (...) Kreślenie linii odbywa się zawsze w jednaki sposób z powodów niezależnych od dziecka, następnie staje się różnorodne, zmienne (...). Cechą decydującą początkowego okresu jest w każdym razie to, że rytm jest początkiem i zasadą rysowania i nawet w końcowym, subtelnym ukształtowaniu zaznacza się jako taki” (za: Szuman 1990: 12).

Wśród wielu badaczy twórczości plastycznej dziecka najtrafniejsze ujęcie genetycznej teorii ewolucyjnej rysunku dziecka z podziałem na okresy przedstawił Cyril Burt (za: Read 1976: 132), który biorąc pod uwagę okres bazgroty, określił ją na wiek 2-5 lat, gdzie punktem szczytowym jest 3. rok życia dziecka. Z kolei Kurt Schwerdtfeger (za: Borzym 1968: 606) zauważa, że pierwsze rysunki dziecka są wyrazem doskonalenia się motoryki, a ich podłożem jest popęd do zabawy. Brak w nich poczucia przestrzeni, tzn. prawa i lewa strona, góra i dół nie są jeszcze odróżniane. Stwierdza, że dopiero gdy dziecko zaczyna z góry planować coś przedmiotowego, staje się to punktem wyjścia rysunku we właściwym tego słowa znaczeniu. Rysunki cechują emocjonalność i prostota form (za: Borzym 1968: 606). Marthe Bernson (za: Parnowska-Kwiatowska 1960: 3) traktuje bazgroty jako przejaw rozwoju osobowości dziecka, opierając się na dorobku grafologii i teoriach psychoanalitycznych. Z kolei Georges Henri Luquet (za: Szuman 1990: 10) uznaje za rysunki bazgroty, które mają nawet niewielkie podobieństwo do tego, co mają przedstawiać. W analizie okresów rozwoju twórczości rysunkowej Luqueta istotne znaczenie ma pojęcie realizmu. Dla Luqueta, jak pisze Cambier, ,pojęcie to świadczy o pragnieniu dziecka, które zdając sobie sprawę ze swoich możliwości, stara się oddać rzeczywistość i w konsekwencji wyławia z obrazu jedynie jego moc narracyjną, jakbyśmy powiedzieli dzisiaj jego wartość znaczeniową" (1993: 34). Błąd Luqueta w ujęciu twórczości rysunkowej dziecka jako realizmu polegał na połączeniu w jedną całość rozwojową realizmu dziecięcego i wizualnego przy równoczesnym stwierdzeniu, że rzeczywistość dziecka wzoruje się na rzeczywistości dorosłego, podczas gdy - jak stwierdził Jean Piaget - realizm dziecięcy wynika z percepcji egocentrycznej, a ,polega na ignorowaniu Ja i uznaniu własnej perspektywy za absolutną i obiektywną" (Cambier 1993: 34).

Według Stefana Szumana rozwój rysunkowy dziecka ,pod względem technicznym i pod względem psychologicznych podstaw tej techniki polega na rozbudowaniu pierwotnych zasadniczych ruchów, wytwarzających pierwotne zasadnicze kształty rysunkowe" (1990: 15). Zmiana formy bazgroty jest wynikiem szeregu „umyślnych” modyfikacji ruchów ręki przez dziecko (Szuman 1990: 11). Natomiast Maria Parnowska-Kwiatowska definiuje bazgrotę jako wytwór - rysunek (w szerokim rozumieniu, tzn. obejmującym 
wszelkie wytwory graficzne dziecka), „który w przeciwieństwie do rysunku właściwego odznacza się bezładną, nie uporządkowaną treścią graficzną i brakiem treści pojęciowej usprawiedliwionej odpowiednią formą" (1960: 12). Okres bazgrot Victor Lowenfeld i William L. Brittain (1977) nazywają okresem kinestetycznym czy autoekspresji, w którym dziecko jest zafascynowane ruchem własnej ręki. Hans Meyers $(1957,1971)$ zaś opisał bazgroty pod kątem czasowego następstwa.

\section{Etapy rozwoju bazgroty dziecięcej w rysunku}

W większości opracowań przyjmuje się, że okres bazgrot występuje u dziecka w wieku od 1,5 roku do 3 lat. Bazgroty dzieli się na: niekontrolowane, kontrolowane oraz na kontrolowane i nazywane. Na przestrzeni badań nad rysunkiem dziecka bazgroty różnie klasyfikowano i opisywano. Wśród badaczy rysunku dziecięcego m.in. Burt podzielił bazgroty na następujące fazy:

1. bazgroty bezcelowe, które cechują wyłącznie ruchy mięśni, poczynając od ramienia, kierowane zazwyczaj od prawej strony do lewej;

2. bazgroty celowe, dziecko zwraca uwagę na gryzmolenie - rysowanie i przy okazji nadaje mu nazwę;

3. bazgroty odtwórcze, w czasie ich rysowania ciągle głównym przedmiotem zainteresowania są ruchy mięśni, lecz poczynając od przegubu ręki; tendencja do skoncentrowania ruchu na palcach, głównie jako skutek naśladowania ruchów rysujących osób dorosłych;

4. bazgroty zlokalizowane, wówczas dziecko próbuje przedstawić określone części przedmiotu. Jest to studium przejściowe do okresu następnego (za: Read 1976: 132).

Luquet wyróżnił m.in. następujące okresy w rozwoju twórczości rysunkowej dziecka, biorąc pod uwagę bazgrotę:

1. realizm braku od 9. miesiąca do 2. roku życia;

2. realizm przypadku 2.-3. roku życia;

3. realizm intelektualny 4.-10. roku życia (za: Szuman 1990: 10).

Arno Stern (1959) wskazał dwa okresy w rozwoju twórczości plastycznej dziecka:

1. studium rysunku prefiguratywnego;

2. studium rysunku figuratywnego (za: Borzym 1968: 604).

Stadium rysunku prefiguratywnego odpowiada okresowi bazgrot.

Jadwiga Cybulska-Piskorek (1976), opierając się na klasyfikacji Stefana Szumana (1990), wyróżniła:

1. mechaniczną bazgrotę (czyli niekontrolowaną),

2. bazgrotę zaawansowaną (czyli kontrolowaną i nazywaną) oraz w obrębie bazgroty zaawansowanej - rysunek tematyczny, który rozwija się równoległe z elementami bazgroty i obejmuje już wiek 4 i 5 lat. 


\section{Bazgroty niekontrolowane}

Pojawiają się w pierwszym etapie bazgrot, w czasie ich powstawania dziecko często nie patrzy na to, co rysuje, kreski powstają mechanicznie, wyłącznie dzięki rytmicznym ruchom ręki, bez kontroli oka. W początkowych bazgrotach dzieci bazgrzą mechanicznie, ponieważ bazgroty dziecięce są wyrazem „technicznego” rozwoju rysowania (zygzaki odpowiadające wahadłowym ruchom ramienia, później drobniejsze kształty, linie krzywe odpowiadające rytmicznym ruchom ręki w stawie nadgarstkowym). Najpierw dziecko rysuje, nie odrywając ołówka od papieru. Linie oderwane pojawiają się później. Wymagają one specjalnych oderwanych impulsów. Dziecko zaczyna z czasem regulować swoje ruchy kredką i tym samym różnicować linie pod względem wielkości, siły i kierunku. Uczy się kreślić linie dłuższe, krótsze, w końcu wykonuje szybkie uderzenia czubkiem kredki o papier. Uczy się robić punkty. Z czasem robienie kropek sprawia mu wielką przyjemność, chętnie bawi się w ten sposób. Zmiana formy bazgroty jest wynikiem szeregu „umyślnych” modyfikacji ruchów ręki przez dziecko. W pierwszym okresie dziecko doskonali zatem podstawową technikę rysowania przez czynne doświadczenie (Szuman 1990).

Pierwszym etapem w rozwoju twórczości plastycznej dziecka wyróżnionym przez Lowenfelda jest etap autoekspresji trwający od 2. do 4. roku życia, który obejmuje bazgrotę. Dziecko po raz pierwszy odkrywa rysunek (Lowenfeld, Brittain 1977). Bezładne bazgroty nie podlegają kontroli wzrokowej. Dziecko nie jest gotowe do wykonywania zadań, które wymagają precyzyjnej kontroli motorycznej ruchów. Dopóki dziecko nie podda kontroli wzrokowej ruchów podczas rysowania - bazgrania, nie ma sensu wymaganie od niego, by kontrolowało inne swoje czynności. Dzieci twórcze bazgrzą, nie ulegając wpływom zewnętrznym.

Rudolf Arnheim stwierdza, że rysunki małych dzieci świadczą o niepełnej kontroli motorycznej. Linia jest pierwszą i pierwotną formą rysunku dziecięcego. Może wynikać z pierwszego mimowolnego zachowania motoryczno-rysunkowego dziecka, które jest widoczne w wyniku nieuświadomionego ruchu ręki i trzymania w niej narzędzia rysunkowego. Arnheim (1978: 189) uważa, że linia jest najprostszym kształtem rysunkowym, który w tym etapie rozwoju dziecka pojmuje jego umysł. Pierwsza jest bazgrota linearna, a nie barwna. Lowenfeld i Brittain (1977) opisują, że dziecko stosuje kolory w stadium nazywania bazgrot $\mathrm{w}$ celu podkreślenia różnych znaczeń. W pracach malarskich dzieci wyrażają swoje doświadczenia emocjonalne i typ osobowości. „Dzieci, które stale malowały w ciepłych barwach, przejawiały swobodne, emocjonalne zachowanie w miłych, serdecznych stosunkach; dzieci, które wołały kolor niebieski, na ogół bardziej kontrolowały swoje zachowanie; natomiast dzieci posługujące się barwą czarną wykazywały niedostatek zachowań emocjonalnych. (...) Barwa, jako element procesu bazgrania, odgrywa w malowaniu rolę głównie eksploracyjną, a stosowanie poszczególnych kolorów może wiązać się ściślej z rozmieszczeniem barw na palecie niż z emocjonalnymi problemami dziecka. Zmiany barw mogą być niekiedy istotne w stadium nazywania bazgrot, ponieważ 
już wtedy barwy mogą mieć pewne znaczenie dla dziecka" (Lownenfeld, Brittain 1977: 61). Anna Trojanowska (1971) pierwsze bazgroty barwne niekontrolowane dziecka nazywa „kleksowatymi” plamami. Zwraca uwagę, że kolor dziecko dobiera przypadkowo, a z czasem o jego wyborze decyduje czynnik emocjonalny. Dziecko lubi barwy chromatyczne (podstawowe i pochodne), czyste (niemieszane z innymi barwami, proste) (Trojanowska 1983: 12).

\section{Bazgroty kontrolowane}

Wystąpienie kontroli wzrokowej dziecka nad ruchami ręki powoduje, że bazgrota staje się kontrolowana i tym samym się zmienia. Dziecko śledzi wzrokiem ruchy ręki i je poznaje. Impulsem do działania staje się kontrola wzrokowa, gdy pojawiają się zaczątki świadomości wzrokowej w rysunku dziecka. Pojawia się intencja w rysowaniu kierowana wzrokiem. Kształtuje się koordynacja wzrokowo-ruchowa (motoryczna) nad śladami rysunkowymi ruchów ręki dziecka. Jest to bardzo ważny moment w przejściu dziecka na następny etap rozwoju rysunkowego. Bazgrota jest to okres działania w sferze percepcyjno-motorycznej, można dodać: enaktywnej (Bruner 1978). Włączenie kontroli wzroku w czasie rysowania bazgrot wiąże się z kształtowaniem się u dziecka „pojęć postrzeżeniowych, [polega] na chwytaniu integralnych cech struktury" (Arnheim 1978: 8). Jak przyjmuje Szuman (1990), dziecko zdobywa w pewnej mierze panowanie woli nad ruchami rysowania, umie narysować to, co chce: albo punkt, albo kreskę. Dziecko rysuje kreski obok siebie, a nie krzyżujące się. Zaczyna kierować ołówkiem, podczas gdy dotąd kierowało tylko ręką, nieświadome kształtu, które ona kreśli. Przed świadomością dziecka staje kształt, forma, podczas gdy dotąd miało ono tylko świadomość ruchu i rytmu przy rysowaniu. „Ruch krystalizuje się i hipostazuje się w kształcie narysowanym” (Szuman 1990: 12). Decydującym krokiem w rysowaniu „przedmiotów” staje się rysowanie kółek lub wieloboków, czyli zamykanie płaszczyzny ramami konturu. Rysowanie kółek jest pewnym szczeblem dojrzałości rysunkowej, która poprzedza rysowanie przedmiotów. W okresie bazgrot dziecko zdobyło panowanie nad pierwotną techniką posługiwania się liniami, kredką, kierowania ruchami ręki, aby ich wynikiem były kreski o zamierzonym kształcie.

Lowenfeld i Brittain (1977) zwracają uwagę, że około 6 miesięcy po tym, jak dziecko zaczęło bazgrać, odkrywa, że istnieje związek między jego ruchami ręką a śladami - znakami na papierze. Dziecko stosuje kontrolę wzrokową nad znakami, które stawia. Uzyskanie kontroli nad ruchem jest dla niego doniosłym doświadczeniem i odkryciem. Dziecko rysuje linie pionowo, poziomo lub koliście. Rzadko spotyka się kropki lub powtarzające się małe figury. Dziecko spędza na rysowaniu dwa razy więcej czasu niż poprzednio i lubi wypróbować na kartce różne kolory. W wieku 3 lat stosuje chwyt kredki zbliżony do tego, jakim posługują się dorośli. Mając 3 lata, potrafi skopiować koło, lecz nie potrafi skopiować kwadratu. Związek między wyobrażeniem wzrokowym przedmiotu, o którym wspomina dziecko, a rysunkiem jest bardzo słaby. Dziecko odkrywa krągłości, łuki, linie proste, łamane itp. W toku spontanicznego rozwoju dzieci przyswajają sobie najpierw 
stosunek pion-poziom, a później przechodzą do kierunków skośnych. Wyrabiają sobie pojęcia przedstawieniowe, bez których nie mogłyby się zajmować coraz bardziej złożonymi kształtami i związkami kształtów. Forma obrazowa rozwija się od najprostszych do coraz bardziej złożonych w procesie stopniowego różnicowania (Arnheim 1978: 177). U małych dzieci występuje przedstawieniowy aspekt zachowania motorycznego.

Koło, które się wyłania z bazgrot dzieci, jest pierwszym zorganizowanym kształtem. Arnheim określa to zdarzenie rysunkowe jako ,jeden z cudów natury” (1978: 181). Pisze, że pierwsze spirale świadczą o koordynacji zachowania motorycznego zgodnie z zasadą prostoty. „Koło jest najprostszym kształtem, jaki można uzyskać w medium obrazowym, ma bowiem centryczną symetrię we wszystkich kierunkach. (...) W rzeczywistości zamierzona krągłość nie istnieje dopóty, dopóki dziecko nie opanuje innych kształtów, linii prostych i załamań pod kątem. W stadium, w którym dziecko zaczyna rysować koła, kształt nie jest różnicowany. Koło nie oddaje krągłości, lecz jakąś ogólniejszą cechę mającą świadczyć, że coś jest »rzeczą«, że jest uchwytne, zwarte i wyróżnia się z pozbawionego wyrazistego charakteru tła" (Arnheim 1978: 182, 183).

Później dziecko tworzy wzory słonecznikowe. Zasada różnicowania mówi, że rozwój organiczny zawsze przebiega od najprostszego do coraz bardziej złożonego. Koło nie jest kołem „(...) dopóki nie zostanie wyraźnie przeciwstawione innym, nacechowanym kształtom, takim jak kwadraty, trójkąty. Wskutek przeciwstawienia innym kształtom koło zyskuje szczególną funkcję semantyczną: zaczyna desygnować okrągłość” (Arnheim 1978: 188). Narysowanie koła przez dziecko jest prawdziwym odkryciem, imponującym osiągnięciem, do którego dochodzi po długim i żmudnym eksperymentowaniu.

Piaget $(1966,1992)$ wykazał, że dziecko w wieku do 3 lat nie różnicuje znaczeń, cechuje je synkretyzm. Na ten problem zwrócili również uwagę Szuman (1985b), Lew S. Wygotski (1989), Maria Kielar-Turska (1992). Pierwsze struktury w rozwoju wyższych funkcji psychicznych nazywam za Wygotskim prymitywnymi. Są one zabarwione emocjonalnie i cechuje je prymat całości względem części. Pierwszy rysunek dziecka, który nazwano bazgrotą, przejawia właśnie te cechy. Cechuje go synkretyzm. Przypuszczam, że rysunek koła w okresie bazgrot jest wyrazem całościowego pojmowania świata przez dziecko w wyniku polisensorycznego nabywania doświadczeń i informacji w wieku niemowlęcym i poniemowlęcym. Zastanawiając się nad formą koła w rysunku dziecka, można przyjąć, że jest to archetypiczna forma graficzna, która wyraża ową idealną jedność świata, prezentującą umysł dziecka.

Rotacyjne ruchy dłoni i pojawienie się czynności mięśni zginających kciuk sprawiają, że na początku 3. roku życia stają się możliwe kreski koliste i przerywane. Dochodzą zmiany ruchowe w percepcji i koordynacji wzrokowo-ruchowej, które pozwalają już około 2. roku życia na ograniczenie kreski do przestrzeni graficznej wyznaczonej przez kartkę papieru. Pojawia się w tym wieku „kontrolowanie punktu wyjścia”, które pozwala na doczepianie kresek do linii już istniejących. Również kontrolowanie punktu końcowego występuje dopiero około 2,6 roku życia. Ta podwójna kontrola pozwoli na realizację figur zamkniętych, co stanowi moment sprzyjający pojawieniu się funkcji symbolicznej 
(Cambier 1993: 42). U dziecka pojawia się uczucie przyjemności, które związane jest z zabawą przedmiot-kreska, podobne do tego, jakie występuje w grach symbolicznych.

„Igranie liniami i zdobywanie zasadniczych, podstawowych form liniowych w pierwszym okresie rysowania u dzieci ma zatem pierwszorzędne znaczenie. (...) Rysowanie jest specjalnie ciekawym rodzajem ruchu, jest ruchem, którego graficzny efekt widzi się i śledzi oczyma, jest ruchem powstającym pod kierownictwem wzroku. (...) Między ruchem a obrazem wyniku ruchu - rysunkiem, musi się zatem utworzyć szereg skojarzeń, umożliwiających przemianę obrazu wzrokowego na ruch i na odwrót" (Szuman 1990: 13, 14). Później sam widok kształtu lub jego wyobrażenie to wystarczająca podnieta do wykonania rysunku. Dziecko początkowo wyobraża sobie tylko kształt ruchu, później również obraz rysunku, który ma powstać. „Kreski rysowania zostają w ten sposób podporządkowane woli. (...) Jednakże dzięki dążeniu wyobraźni do określoności form i linii, kształty stają się coraz wyraźniejsze, zdecydowane. Z chaosu rodzi się forma" (Szuman 1990: 14). Okres bazgrot wieńczy umiejętność zamknięcia linii w koło oraz kreślenie kierunków pionowych, poziomych i krzyża. Jest to, moim zdaniem, znaczący fakt, który pozwala stwierdzić, że rozwój dziecka przebiega prawidłowo nie tylko od strony jego koordynacji wzrokowo-motorycznej, rysunkowej, ale i psychicznej.

\section{Bazgroty kontrolowane i nazywane}

Z czasem dziecko uświadamia sobie, że kształty narysowane na papierze mogą zastępować wszelkie przedmioty, do których pozostają w stosunku znaczący-znaczony (Arnheim 1978: 182). Każda formalna właściwość obrazu musi wypływać w jakiś sposób z obserwacji fizycznego świata. Bardzo znaczącym odkryciem i doświadczeniem rozwojowym dziecka jest nazywanie bazgrot, które są spontanicznymi znakami plastycznymi o charakterze abstrakcyjnym (Szuścik 2006). W momencie, w którym dziecko zaczyna dostrzegać związek między intencją rysowania i nadaniem treści bazgrotom, zmienia się jego myślenie z kinestetycznego na wyobrażeniowe. Dzieje się to zwykle około 3,5 roku życia dziecka. Wówczas kształtuje się u dziecka podłoże pamięci wzrokowej. Ilość czasu spędzanego na rysowaniu znacznie się zwiększa, a bazgroty stają się bardziej zróżnicowane. Rysunek staje się teraz zapisem tego, co dziecko sądzi o różnych elementach swego otoczenia, a ten sposób rysowania powoduje, że bazgrota staje się ważnym środkiem komunikowania się. Gdy dziecko wchodzi w fazę bazgrot nazywanych, stosuje również różne barwy do podkreślenia różnych znaczeń. Dziecko rozróżnia kolory, wybiera je (Lowenfeld, Brittain 1977). Gdy dziecko zaczyna nazywać swoje bazgroty, wówczas jego oryginalność i zdolność twórcza stają się szczególnie widoczne. Słowo zaczyna towarzyszyć dziecku w procesie rysowania. $Z$ procesem rysowania jest ściśle związany proces rozwoju mowy dziecka. Można przypuszczać, że z czasem słowo pomaga dziecku w przestrukturyzowaniu formy rysunku od form prostych do bardziej złożonych. Rozumiem przez to, że słowo i percepcja przedmiotu przekształcają i ukierunkowują aktywność rysunkową dziecka oraz określają i utrwalają treść rysunku. Z kolei rysunek w rozwoju mowy po- 
budza narrację dziecka zarówno na początku procesu rysowania, w jego trakcie, jak i po wykonaniu rysunku, kiedy dziecko o nim opowiada. Tak więc rysunek i słowo oddziałują na siebie stymulująco. W miarę rozwoju dziecko tworzy za pomocą rysunku struktury systemów znaczących. Dziecko rysuje nie obraz przedmiotu, lecz naturalne znaki plastyczne, które są śladami tworzonymi spontanicznie, monosubiektywnymi, których nie określają żadne reguły znaczeniowe (Szuścik 2006). Mimo że nie rysuje obrazu przedmiotu, w umyśle ma wykształcony jego obraz w wyniku poznania polisensorycznego i rozwoju działania (Szuman 1985a, 1955). Można przypuszczać, że okres bazgrot jest bardzo istotny w rozwoju rysunkowym dziecka, ponieważ wówczas kształtują się relacje między reprezentacjami: enaktywną, ikoniczną i symboliczną (Bruner 1978), które stopniowo doprowadzają dziecko do rysunku obrazu przedmiotu. Jednymi z najważniejszych form działań symbolicznych dziecka są mowa i rysunek. W początkowym etapie rozwoju bazgroty dziecięcej nie ma ona znaczenia, natomiast w dalszym rozwoju rysunkowym dziecka nabiera wagi dzięki temu, że ono jej to znaczenie nadaje, je nazywa. Bazgrota jest pierwszym spektakularnym przejawem jednoczenia się słowa i wizerunku plastycznego w przedstawianiu jakiegoś przedmiotu. Dalej dziecko coraz precyzyjniej nazywa formy rysunkowe. Wiąże się to z umiejętnością identyfikacji form graficznych z odpowiadającymi im słowami. Te dwa procesy rozwojowe wzajemnie się wzmacniają i kontrolują. Jest to szczególnie ważne w rozwoju dzieci w wieku przedszkolnym, gdzie obraz i rysowanie są obecne w edukacji i w przygotowaniu do nauki pisania. Pojawiają się powtórzenia w języku mówionym i w formie rysunkowej dziecka, które utrwalają jego wiedzę oraz doświadczenia w zakresie spostrzeżeń, pojęć i działań (Szuścik 2006).

\section{Zakończenie}

W okresie rysowania przez dziecko na poziomie bazgrot mamy do czynienia z nieświadomym, spontanicznym działaniem, które z czasem przechodzi w świadome i kontrolowane (ślad - kształt - znaczenie). Bazgrotę dziecięcą cechują: dynamika zmiany, spontaniczność działania, kinestetyczność elementarna w budowaniu formy, nieprzedmiotowość, własny wewnętrzny rytm rysowania, malowania, subiektywność, projekcja postaci fizycznej aktywności, bajeczność treści, nowość wyników, oryginalność ujęcia i ekspresyjność.

W rysunku dziecięcym następuje ewolucja form pod wpływem wewnętrznej dynamiki rozwoju dziecka, dziecko z czasem odkrywa w geście, że może podjąć decyzję, wpłynąć na charakter gestu i jego zapisu rysunkowego. Tworzy tym samym niepowtarzalne spontaniczne znaki plastyczne. Bazgrota i inne formy aktywności plastycznej są odmianami zachowania motorycznego, które rozwinęły się z ruchu ekspresyjnego i opisowego. Najlepszym przygotowaniem do tworzenia jest więc własne działanie dziecka. Twórczość plastyczna jest dla niego przede wszystkim środkiem wyrazu. Bazgranie jest ekspresją twórczą. Dziecko, bazgrząc, odczuwa przyjemność i potwierdza swoje istnienie. Bazgranie dziecięce jest dla niego znaczącym doświadczeniem. Bazgroty to zapomniane i ,zapodziane znaki 
dziecka" (Łukaszewicz 2000). Moim zdaniem bazgrota odgrywa znaczącą rolę w rozwoju twórczości plastycznej dziecka i jego rozwoju ogólnym. Powinniśmy mieć większe zaufanie do dziecka i jego możliwości na etapie zarówno jego edukacji przedszkolnej, jak i wczesnoszkolnej. Niech samodzielnie doświadcza, odkrywa, pokonuje przeszkody i rozwiązuje problemy, odczuwa radość z własnych dokonań.

Czas na swobodne bazgranie dziecka, które jest mu przypisane w jego pierwszym etapie rozwoju twórczości rysunkowej, jest ważnym czasem dla jego rozwoju twórczego, motywacji do poznawania i działania, które dadzą mu dobre podstawy do dalszych etapów jego działań i uczenia się. Pozwólmy dzieciom na bazgranie, kiedy jest czas ku temu w ich twórczości rysunkowej, a szerzej - w ich życiu.

\section{Literatura}

Arnheim R. (1978), Sztuka i percepcja wzrokowa. Psychologia twórczego oka. Warszawa, WAiF.

Borzym I. (1968), O wychowaniu estetycznym i twórczości rysunkowej dzieci. W: L. Wołoszynowa (red.), Psychologia rozwojowa, wychowawcza i spoleczna. Seria 2. T. 3. Warszawa, PWN.

Bruner J.S. (1978), Poza dostarczone informacje. Warszawa, PWN.

Cambier A. (1993), Aspekty genetyczne i kulturowe W: Ph. Wallon, A. Cambier, D. Engelhart, Rysunek dziecka. Warszawa, WSiP.

Cybulska-Piskorek J. (1976), Twórczość plastyczna dziecka $w$ wieku przedszkolnym. Warszawa, WSiP.

Debesse M. (1988), Zdolności twórcze i zajęcia rozwijajace ekspresję. W: M. Debesse, G. Mialaret (red.), Rozprawy o wychowaniu. Filozoficzne, psychologiczne i socjologiczne aspekty wychowania. T. 1. Warszawa, PWN.

Kellog R. (1969), Analyzing Children's Art. California, National Press Books.

Kellog R., O'Dell S. (1967), The Psychology of Children's Art. California, Del Mar.

Kielar-Turska M. (1992), Jak pomagać dziecku w poznawaniu świata. Warszawa, WSiP.

Lowenfeld V., Brittain W.L. (1977), Twórczość a rozwój umysłowy dziecka. Warszawa, PWN.

Łukaszewicz R. (2000), Dziecko pozostaje symbolem przyszłości. W: K. Leksicka, Dzieci w labiryncie świata. Wrocław, Fundacja Wolne Inicjatywy Edukacyjne.

Machón A. (2013), Children's drawings. The Genesis and Nature of Graphic Representation a Developmental Study. Madrid, Fibulas Publishers.

Meyers H. (1957), Die Welt der kindlichen Bildnerei. Witten, Luther-Verlag.

Meyers H. (1971), Die Welt der kindlichen Bildnerei. Ravensburg, Auflage Otto Maier-Verlag.

Parnowska-Kwiatowska M. (1960), Bazgrota i rysunek dziecka. Warszawa, NK.

Piaget J. (1966), Studia z psychologii dziecka. Warszawa, PWN.

Piaget J. (1992), Mowa i myślenie dziecka. Warszawa, PWN

Read H. (1976), Wychowanie przez sztukę. Wrocław-Warszawa-Kraków-Gdańsk, Zakład Narodowy im. Ossolińskich.

Richter H.-G. (1997), Die Kinderzeichnung: Entwicklung, Interpretation, Ästhetik. Berlin, Cornelsen Verlag.

Stern A. (1959), Compréhension de l'art enfantin. Neuchâtel, Éditions Delachaux-Niestlé. 
Szuman S. (1927), Sztuka dziecka. Psychologia twórczości rysunkowej. Warszawa, Książnica „Atlas”.

Szuman S. (1955), Rola działania w rozwoju umystowym małego dziecka. Wrocław, Zakład Narodowy im. Ossolińskich.

Szuman S. (1985a), Geneza przedmiotu. W: S. Szuman, Dzieła wybrane. T. 1: Studia nad rozwojem psychicznym dziecka. Wybór i oprac. M. Przetacznikowa, G. Makiełło-Jarża. Warszawa, WSiP.

Szuman S. (1985b), Obserwacje dotyczace tak zwanego synkretycznego spostrzegania u dziecka. W: S. Szuman, Dzieła wybrane. T. 1: Studia nad rozwojem psychicznym dziecka. Wybór i oprac. M. Przetacznikowa, G. Makiełło-Jarża. Warszawa, WSiP.

Szuman S. (1990), Sztuka dziecka. Psychologia twórczości rysunkowej. Warszawa, WSiP.

Szuścik U. (2006), Znak werbalny a znak plastyczny w rozwoju twórczości rysunkowej dziecka. Katowice, Wydawnictwo Uniwersytetu Śląskiego.

Szuścik U. (2019), Bazgrota w rozwoju twórczości plastycznej dziecka. Katowice, Wydawnictwo Uniwersytetu Śląskiego.

Trojanowska A. (1983), Dziecko i plastyka. Warszawa, WSiP.

Trojanowska-Kaczmarska A. (1971), Dziecko i twórczość. Wrocław, Zakład Narodowy im. Ossolińskich, Wydawnictwo PAN.

Wygotski L.S. (1978), Narzędzie i znak w rozwoju dziecka. Warszawa, PWN.

Wygotski L.S. (1989), Myślenie i mowa. Warszawa, PWN. 